\title{
Pragmatic Study of Speech Act Analysis in Discussion Activities on Students' Speaking Learning
}

\author{
Widiastuti \\ STIM Lasharan Jaya Makassar \\ Email:widiastuti@live.com
}

\begin{abstract}
The research aims to know the types and functions of speech acts that appear in discussion activities on speaking learning of 3rd semester students of Polytechnic ATI Makassar. The methods of this research is a descriptive qualitative method. Data collection techniques carried out through observation, recording techniques,and notes taking techniques The subject of this research is the 3rd semester Polytechnic ATI Makassar students in class A and B in discussion activities. Data analysis techniques in this research are:(a). Transcribe recorded data into written form, (b).Identifying forms of speech acts that have been transferred into written form, (c). Identify the meaning of pragmatics in speech acts then (d).Data are presented in the form of descriptions as they are. The results of the data analysis shows that there are several types of speech acts found. Based on the action objectives of the speaker's perspective, Locutionary act, Illocution act, and perlocutionary act are found. Locutionary Speech Acts Include News, Asking and Commanding Illocutionary Speech Acts include Assertives, Directives, Expressives, Commissives and Declaratives Illocutionary Act.
\end{abstract}

Keywords: Speech Act, Locutionary Act, Illocutionary Act, Perlocutionary Act, Speaking Learning, Class Discussion.

\section{INTRODUCTION}

Language cannot be separated from human life, language has an important role for humans, language being able to express some thoughts, feelings, hopes, ideas, and opinions to others. This is in accordance with the function of the language itself, namely as a means of interacting or communicating, both oral and written (Fakhruddin, Selle, and Nurchalis 2019).

One of the lessons in the classroom, especially speaking, which involves speakers and speech partners is a discussion activity (Aswad 2017). In the discussion activities, there is a change of roles between the speaker and the speech partner in expressing opinions or ideas conveyed. In this case, it is found that students' speeches express their opinions, ask questions, give rebuttal, order, give permission and offer and so forth. Communication processes that take place, occur at the same time and this is greatly influenced by certain events and situations. The explanation above confirms that, the intention that 
is in the utterance of the speaker cannot be separated from the context of the situation and events in the communication so that, students in this case are required to be able to use language that is able to be accepted, understood and influence other students as opposed to speech

Researchers are interested in the title because of the phenomenon that there are still many students who do not pay attention to politeness in speaking because the speech delivered by the interlocutor is direct speech acts and indirect speech acts that contain meaning that must be understood by the speaking partners, namely 3rd semester students of Polytechnic ATI Makassar.

The researcher chooses 3rd semester students in the A and B class of Polytechnic ATI Makassar as the object of research because in that class there are variations in the language used by students when discussing, the language used should be formal language so easily understood by opponents of the speaker. This is what makes researchers interested in taking objects in the third semester.Speech that occurs in a language interaction has a variety of purposes to be conveyed. With regard to these various purposes, Leech (1993: 19-20) states that a speech act covers (1) the speaker and the speech partner (2) the context of the speech, (3) the purpose of speech (4) speech act as a form of action or activity (5) speech as a verbal act product. Speech act is one of the objects of pragmatic study. Pragmatics studies how language is used in communication, and has meaning as context, not something that is abstract in communication. Based on the description, the meaning which becomes pragmatic study is context bound meaning.
The speaker and the interlocutor can use the context to make it easier to understand the meaning of the speech. The use of spoken language in learning in schools is one form of communication that takes place in classroom interactions. Communication that is established between students in particular is expected to channel their ideas or ideas so that they can be understood, accepted, and followed by others as opposed to speech (Aswad et al. 2019). Learning English, especially speaking skills required by lecturers and students to support the smooth communication process in the classroom. In learning speaking skills, students are required to be able to convey ideas and develop their potential in official forums related to learning material(Nurchalis, Selviana, and Riza 2019).

In this study Polytechnic ATI Makassar as the place of research because the campus never conducts of direct speech and indirect speech acts studies. However, based on the data and findings that are studied by researchers each individual has its own validity and character in speaking. In addition, the social and cultural backgrounds faced by each region are also different so as to create different speech acts.

This research is in line with research that has been done by previous researchers, namely Sri Meiweni Basra with the research title A speech act analysis of teacher talk inian EFL Classroom. The study concludes that the choice of speech acts classification determine the teaching approach and vice versa. It is recommended for English teachers wishing to help students to achieve communicative competence to use more directive speech acts. Next Nurwahidah (2014) which examines the relation 
of speech acts, the pragmatic meaning of speech acts and politeness of speech acts, and by Merdana with the research tittle is an analysis of speech acts produces by Elementary school Teachers and Students to facilitate teaching and learning at SDN Pringgasela East Lombok. This study found that the teachers produced more utterances $(72.59 \%)$ than students did (27.41\%). The teachers mostly produced directives type of speech acts, while the students' speech acts were mostly assertives namely, responses to the teachers' directions.

Based on the explanation above, the researcher focused on direct speech acts and indirect speech acts on the Polytechnic ATI Makassar students. This is interesting to study in depth, because there are still many students who have not been able to communicate and speak well.

\section{METHOD}

The research subjects is the $3 \mathrm{rd}$ semester students of Polytechnic ATI Makassar in class discussion activities. The object of this research is the speech acts carried out by students in class discussion activities in speaking learning of students of 3rd semester in the Polytechnic ATI Makassar. As the object of research is the third semester of $A$ and class $B$.The researcher's reason in chosing Polytechnic ATI Makassar as the location of the research because the campus has never conducted research on direct speech and indirect speech acts and the reason the researchers chose third semester students because in the class there are variations in the language used by students when discussing, the language used should be formal language so that it is easily understood by opponents of the speaker.This is what makes researchers interested in taking objects in the third semester.

This research uses descriptive qualitative method this means that this study tries to record carefully all linguistic phenomena in accordance with what they are. This research is focused on direct speech acts and indirect speech act which is spoken by students of the third semester of Polytechnic ATI Makassar.

In this study the the main instrument is the researcher himself by making direct observations to collect data that meet the criteria as research data, namely observation guidelines, recording devices and notes. Data collection techniques carried out through observation, recording techniques, and notes taking techniques.

\section{RESULT}

The data obtained and discussed are speech acts contained in discussion activities on speaking learning by the 3 rd semester students of Polytechnic ATI Makassar.

In order for this research to have credibility or validity as a researcher's findings, several data validity checking techniques need to be carried out by conducting a credibility test, namely: (1) triangulation of techniques and sources, (2) discussion with colleagues. Data analysis techniques in this research are as follows:

a) Transcribe recorded data into written form.

b) Identifying forms of speech acts that have been transferred into written form.

c) Identify the meaning of pragmatics in speech acts. 
d) Data are presented in the form of descriptions as they are

The types of speech acts found in this research include locutionary act, illocutionary act and perlocutionary acts. Judging from the type of locutionary there are forms of news, questions and ordering.

Judging from the illocutionary speech acts, it is found assertives, directives, expressives, commissives and declaratives illocutionary acts. The most assertive illocutionary speech acts appear in this research, followed by directive, expressive, declarative and finally commissive. Judging from the speech acts of perlocution in this research, it is found that perlocution made the speech partners do something, were persuaded, interested, annoyed, understood, happy, and reduced tension.

Based on the delivery method, direct and indirect speech acts were found. Direct speech acts dominate in this research. Based on the meaning of the words that compose the literal and non-literal speech acts are found. Types of literal speech acts appear more than non literal speech acts. Seen from the intersection of direct, indirect, literal and nonliteral speech acts in discussion activities in the 3rd semester students of Polytechnic ATI Makassar speaking learning, found direct literal, direct indirect literal acts, indirect direct literal acts and indirect indirect literal acts. The literal direct speech act interventions dominate more than the other speech act intersections in this research. For more details, direct, indirect, literal, not literal intersection

Based on research conducted in discussion activities on speaking learning of 3 rd semester students of Polytechnic ATI Makassar, it finds that the speech act functions inform, ask, order, state, mention, show, acknowledge, demand, defend, refute, ask, suggest, complain, insinuate, utter sorry, say thanks, say hello, criticize, praise, allow, forbid, offer, cancel, do something, reduce tension, make happy, make persuasion, make interested, make understand, and make upset.

Locutionary acts that are most commonly find in this studies are news forms with the function of informing as many as 289 speeches while locutionary command forms with commanding functions are found with at least 28 speeches. This happens because most of the speeches made by the presenter (speaker) to the participants (opponents of the speaker) in the discussion activity contain speech describing the results of the presenter's response on the topic of discussion to the interlocutor without influencing the interlocutor to pay attention. Furthermore, the illocutionary speech acts that most often appear are assertive illocutionary with the function of stating as many as 97 speeches while declarative illocutionary with the canceling function appearing less with 1 utterance. That is because in the discussion activities both the speakers and speech partners express more personal and group opinions with a statement containing statements so that the speech partners are interested in giving an explanation

Next, in addition to locutionary and illocutionary acts, it was found that the act of perlocutionary act with the function of doing something more appeared as many as 167 utterances while perlocutionary with the function of reducing the tranquility of fewer appeared as much as 4 utterances. This masking 
Widiastuti

Pragmatic Study of Speech Act Analysis in Discussion Activities on Students' Speaking Learning

DOI: https://doi.org/10.31605/eduvelop.v3i2.616

occurs because the discussion participants paid less attention to the explanation and questions from the speaker.

Based on the method. It found that two types of speech acts, namely direct and indirect speech acts. The type of direct speech acts form news with the function of informing as many as 253 , asking questions with the function of asking as many as 68 speeches and commands with the function of ordering as many as 28 speeches dominating in discussion activities on speaking learning of the 3rd semester students of Polytechnic ATI Makassar. Direct speech acts are often used by moderators, presenters and discussion participants in accordance with the mode of the sentence so that the interlocutor has the same understanding of the speech delivered by the speaker when informing opinions, asking questions, and giving commands in the discussion. Literal and non-literal speech acts were also found in discussion activities on speaking learning of students 3rd semester of Polytechnic ATI Makassar. Literal speech acts in this research appear more than non literal speech acts. News literal speech acts with the function of informing as many as 261 speeches, literals with the function of praising 3 speeches, literals with the function of asking questions 68 and literals with the function of commanding 27 speeches. This is because moderators, presenters and discussion participants want the interlocutor to immediately understand the intent expressed by the speaker, both in expressing opinions, asking questions, giving commands in the discussion by using speech that has the same purpose as the words used by the moderator, presenters and discussion participants. Literal direct speech acts appear more than other speech acts intersection because speakers are moderators, presenters and discussion participants want the speech partners to immediately understand the intended meaning of the speakers with the same speech mode and meaning as the expressions of speech when informing opinions, submitting opinions question and give ordering in the discussion

\section{DISCUSSION}

In the speech act research in the discussion on the third semester students' learning speech at Polytechnic ATI Makassar based on the purpose of the speech act from the perspective of the speaker, It is found that locutionary, Illocutionary, and perlocutionary acts were found. Based on the form of delivery, direct and indirect speech acts were found. In addition, based on the expression of meaning found literal and non-literal speech acts. Speech acts are divided into several types with each function. The following are the types of speech acts with each function in the discussion activities on learning speaking for third semester students of the Polytechnic ATI Makassar

\section{Form and Function of Speech Acts in the discussion on Speaking Learning of the 3rd semester students of Polytechnic ATI Makassar}

\begin{tabular}{|c|c|c|c|c|c|}
\hline $\begin{array}{l}\mathbf{N} \\
0\end{array}$ & $\begin{array}{c}\text { Type of } \\
\text { Speech Act }\end{array}$ & Form & Function & $\begin{array}{l}\text { Sub } \\
\text { total }\end{array}$ & Total \\
\hline \multirow[t]{3}{*}{1} & \multirow[t]{3}{*}{ Locutionary } & News & Informing & 289 & \multirow[t]{3}{*}{384} \\
\hline & & Asking & Asking & 65 & \\
\hline & & Command & Commanding & 30 & \\
\hline \multirow[t]{5}{*}{2} & \multirow[t]{5}{*}{ Illocutionary } & \multirow[t]{5}{*}{ News } & Assertives & 148 & \multirow[t]{5}{*}{384} \\
\hline & & & Directives & 88 & \\
\hline & & & Expressives & 91 & \\
\hline & & & Commisives & 22 & \\
\hline & & & Declaratives & 35 & \\
\hline 3 & Perlocutionary & & $\begin{array}{l}\text { Give the } \\
\text { Effect }\end{array}$ & 384 & 384 \\
\hline
\end{tabular}




\section{a. Locutionary Act}

\section{a) News}

Illocutionaryact is the act of saying something that is not related to the context. Locutionary act of news form in this research can be seen as follows:

Speaker : "In here, we have positive and negative point of view.

Speaker : "The results from the discusiion of our group say that English is important because by mastering English we can easily master of technology.

Speaker : Okay, I will read the results of our group discussion

The speech in the data above is intended by the speaker to inform the discussion participants that the group has two responses, which are positive and negative. The data spoken spoken by the speaker does not contain the intention to influence the interlocutor (discussion participant).

\section{b) Asking}

The form of the asking is formally marked by the presence of question words such as what, who, how much, when, and how with or without particles - is the confirmation. The asking form usually ends with a question mark (?) At the end of the speech. The form of asking consists of two kinds, namely questions that only require a yes or no answer and questions that require an explanation from the person being asked. The location of the asking form in the discussion activity on the speaking learning of the 3rd semester students of Polytechnic ATI Makassar can be seen in the following example.

Participants : "What makes learning English difficult?".

Participants : What do you think about studying English?

Moderator : How about your group?

\section{c) Commanding}

The form of commanding is divided into actual forms of commanding, requests, prohibitions, invitations, and terminations. The form of the commanding has a function so that the interlocutor immediately performs the act ordered by the speaker. The following can be seen examples of speech acts of locution in the form of instructions in the discussion on speaking learning of third semester students of Polytechnic ATI Makassar

a. Moderator : "That's all of our presentation, question and answer session I open".

b. Moderator : Come on please Randi who will come forward to present the results of the discussion

c. Moderator : Be Louder, please!

\section{b. Illocutionary Act}

Illocutionary Act Illocutionary acts are speech acts which in addition to stating something also do something and illocutionary speech acts are very context dependent. Based on the Speech Act 
research in the Discussion on Speaking Learning of the third semester students of the Polytechnic ATI Makassar. It was found that the illocutionary acts were Assertives, Directives, Expressives, Commissives and Declaratives. The following are examples of assertives, directives, expressives, commissives and declaratives illocutionary.

\section{Assertives}

Assertive speech acts are speech that binds the speaker of the truth of what he is saying. Speech types of assertive illocutionary act dominate from all types of illocutionary act. The following examples of assertive illocutionary are found in this research:
a. Speaker : "Do you understand?".
Participants: "Yes I do"
b. Speaker : Anybody want to give a response?

Participant : Yes, I would like to add that the present tense's function in addition to stating daily activities also serves to state absolute truth.

c. Speaker : Thank you for your input. How is that still unclear?

Participant : That's enough, thank you ...

\section{Directives}

Directives speech acts is speech that is intended to have some effect through the actions of the listener.

\section{Expresives}

Expressive illocutionary speech is speech to express, express, or inform the psychological attitude of the speaker towards a statement of the expected state.

\section{Commisives}

Commisive illocutionary speech acts are speech acts that involve the speaker in several actions to come

\section{Declaratives}

Declarative illocutionary speech acts are speech when performance success will lead to a good correspondence between propositional with reality

\section{c. Perlocutionary Act}

Perlocutionary act is a speech that has the effect or the effect that is caused by the speaker's speech towards the speech partner. Based on the research conducted in the discussion on speaking learning of the 3rd semester students of the Polytechnic ATI Makassar, it was found that the following acts of perlocutionary.

\section{Direct Speech}

Direct speech acts are utterances that are expressed directly and are easily understood by the speech partner because the utterances are in the form of straightforward meaningful sentences. Based on research conducted, direct speech acts are functioned conventionally in accordance with sentence modes, namely news 
sentences to reach something, ask questions to ask something and order to order someone to do something.

\section{d. Indirect Speech.}

Indirect speech acts are utterances that are spoken indirectly usually not answered directly, but must be immediately implemented intentions and implications in it.

\section{CONCLUSION}

The speech acts found in the discussion activities on speaking learning of the 3rd semester students of Polytechnics ATI Makassar viewed from the objective of the action from the perspective of the speaker are localized speech acts, illocutionary speech acts and speech acts of perlocutionary act. The speech acts found in the discussion activities on speaking learning of the 3rd semester students of Polytechnic ATI Makassar seen from the expression of meaning are literal speech acts and non-literal speech acts.

Speech act functions found in discussion activities on speaking learning of the 3rd semester students of Polytechnic ATI Makassar are functions of informing, asking, commanding, stating, showing, showing, acknowledging, demanding, maintaining, refuting, asking, suggesting, complaining, insinuating, saying sorry, say thank you, say hello, criticize, praise, allow, forbid, offer, cancel, do something, reduce tension, make happy, make persuasion, make interested, make understand, and make upset.

\section{REFERENCES}

Austin, J.L (1969). Performative Constantive, an Essay in the Philosophy of Language. Cambridge: Cambridge University.

Aswad, Muhammad. 2017. "Is It Truly Improvisational Exercise Push Students' Speaking Ability." EDUVELOP (Journal of English Education and Development) 1 (1): 9-17.

Aswad, Muhammad, Fathu Rahman, I.M Said, B Hamuddin, and Nur Fadillah Nurchalis. 2019. "A Software to Increase English Learning Outcomes: An Acceleration Model of English as the Second Language." 2019. https://www.asian-efl-journal. com/monthly-journals/2019-monthly-journals/ volume-26-issue-6-2-2019/.

Fakhruddin, Zulfah, Amzah Selle, and Nur Fadillah Nurchalis. 2019. "Technology-Based Teaching Material Development Training for Pre-Service Teachers to Improve Students' Learning Outcomes." NOBEL: Journal of Literature and Language Teaching 10 (1): 87-102. https://doi.org/10.15642/ NOBEL.2019.10.1.87-102.

Nurchalis, Nur Fadillah, Selviana Selviana, and Effran Ade Riza. 2019. "Activating Students to Speak English by Using ELTIS Resource Pack." Loquen: English Studies Journal 12 (2'): 76-84. https://doi. org/10.32678/loquen.v12i2`.2092.

Basra, S. M., \& Thoyyibah, L. (2017). A speech act analysis of teacher talk in an EFL classroom. International Journal of Education, 10(1),73-81.doi: (PDF) A Speech Act Analysis Of Teacher Talk In An Efl Classroom.

Brown, G., \& Yule,G. (1983).Discourse Analysis. Cambridge: Cambridge University Press.

Chaer, Abdul dan Leonie Agustina. (2004). Sosiolinguistik. Jakarta: Rineka Cipta.

Center for Advanced Research on Language Acquisition. (2015). Pragmatics and speech acts. University of Minnesota: Center for Advanced Research on Language Acquisition. www.carla.umn. edu/ speechacts/index.html 
Fromkin, et al. (1988). An Introduction to Language. Third ed Sidney: Hartcourt Brace.

Leech, G.N.1983 Principle of Pagmatics. London: Longman.

Nurani, N. P. (2015). A pragmatic analysis of classroom speech acts in the English teaching and learning process at SMA N 1 Purworejo (A Case Study). (Unpublished Thesis). Yogyakarta State University, Indonesia

Nurwahidah. (2014). Analisis Tindak Tutur Siswa SMP Negeri 19 Bulukumba dalam proses pembelajaran (Suatu Tinjauan Pragmatik). Tesis. Makassar: Pogram Pascasarjana Universitas Negeri Makassar.
Oluremi, Ajewole-Orimogunje C. (2016). Speech acts and Welfarist Ideology in Governor Aregbesola’s May 1, (2013) Address. International Journal of English Language and Linguistics Research, 4(4), 23-32

Searle,J.R. 1969. What is a Speech Act, An Essay in the Philosophy of Language. Cambridge University Pres.

Taguchi, N. (2015). Instructed pragmatics at a glance: Where instructional studies were, are, and should be going. Language Teaching 48 (1): 1-50.

Yule,G. (1996). Pragmatic. USA : Oxford UniversityPress.

Wardhaugh, R. (2006). An Introduction to Sociolinguistic (5 $5^{\text {th }}$ Edition Oxford : Blackwell. 